\author{
St udia Philosophic a \\ Wratis lavi e n s i a \\ vol. XV, fasc. $2(2020)$ \\ https://doi.org/10.19195/1895-8001.15.2.2
}

\title{
URSZULA LISOWSKA
}

ORCID: 0000-0003-2177-6732

University of Wrocław

\section{Wonder-through Aesthetics and Environmentalism to Politics}

\begin{abstract}
The paper offers a contribution to the political account of wonder. The rationale for addressing this problem is provided by Hannah Arendt's observations on the paradoxical relationship between wonder and politics - wonder appears here as both essential and indispensable to politics as the realm of opinions (doxai). This quandary corresponds to two common-sense uses of the term "wonder"- as an emotion and as an act of judging. It is argued that the political interpretation of wonder should link these two poles. Drawing on Martha Nussbaum's account of wonder and its reformulation developed by Jeremy Bendik-Keymer, the paper offers such a synthesis by emphasising the environmental and aesthetic dimensions of the concept.
\end{abstract}

Keywords: wonder, philosophy, politics, emotions, judgment, bios, dzoe

Neither philosophy in general nor any of its specific branches can lay exclusive claim to the category of wonder. Quite obviously, the word is commonly used in a variety of senses; most importantly: it operates as both a noun and a verb. In the former function, wonder can refer to a subjective state (the feeling or emotion of wonder) and its possible objects (things, as in "the Seven Wonders of the World", but also persons, as in "a girl wonder" meaning "a girl genius") alike. As a verb, the term describes the act of experiencing the emotion of wonder ("She wondered at his ability to speak out his mind so clearly"). Perhaps less obviously, it can also denote the activity of speculating and making judgments ("I wonder who she is"). Finally - and seemingly least relevantly - the verb is often used in polite requests 
for a favour ("I was wondering if you could help me"). ${ }^{1}$ Thus, as far as the summary of such a diversity of uses is possible, wonder is both a feeling and its object; correspondingly, it likewise refers to the acts of experiencing the emotion and of speculating about its objects. By a small stretch of imagination, the two functions can be said to converge in the last, conventional use of the term: here the other person is perceived as a wonder, whose willingness to cooperate with the speaker is the object (and the intended outcome) of the expressed judgment.

In its attempt to approach wonder as a philosophical category, the paper navigates between all of these dimensions: the subjective-objective, the emotional-intellectual and the interpersonal ones. As the title suggests, the phenomenon of wonder has been located at the crossroads of three philosophical sub-disciplines: political philosophy, aesthetics and environmental ethics. To be specific: while aesthetic and environmental insights are employed to define the specificity of wonder, the concept itself is applied to political philosophy. In other words, the paper draws on aesthetic and environmental concerns to present wonder as a politically relevant category.

The underlying assumption is that, placed against the aesthetic-environmental background, the concept of wonder can make an important contribution to addressing a dilemma fundamental to political philosophy. One formulation of this challenge was provided by Hannah Arendt in her paper Philosophy and Politics. In this essay, Arendt suggested, in a characteristically contradictory manner, that wonder is at the same time detrimental and essential to politics. I argue that this paradox is related to the foundational political task of developing an account of subjectivity. My working hypothesis is twofold: firstly, in its environmental application, wonder takes subjectivity as its object; secondly, due to its aesthetic dimension, wonder offers a method of reflecting on this particular object. After introducing the challenge for wonder based on Arendt's observations, I develop my hypothesis with the help of two other philosophers-Martha C. Nussbaum and Jeremy Bendik-Keymer. I then apply their insights to Arendt's dilemma-hence, the argumentation develops in a spiral movement.

\section{The perplexities of thaumadzein}

Arendt's essay Philosophy and Politics addresses the question of the very possibility of political philosophy. In terms of the Arendtian architectonics, this is but one aspect of the complex relationships between vita contemplativa and vita activa - the two major areas of the human condition, which Arendt liked to starkly distinguish only the better to capture their mutual overlaps. In the case of political philosophy, this essential tension is well reflected by the phenomenon under consideration, i.e. wonder. Following her usual phenomenological method of recovering the obscured meanings of concepts, Arendt recalls the Greek category of thaumadzein, which conveys the idea of wonder as a pathos, "something which

1 Oxford Advanced Learner's Dictionary, 8th Edition, Oxford 2010; Dictionary.com, https://www. dictionary.com/browse/wonder (accessed: 26.02.2019). 
is endured"2 (she thus emphasises only one of the contemporary senses of the concept, the one related to the subjective emotional state). A pathos it has to be, given that its object is defined as "that which is as it is", wonder being an insight into ultimate truths which "befalls" a person's nous (mind) in a fit of a traumatic state. $^{3}$ As soon as this passive state of endurance is transformed into an active attitude of an articulate judgment, the peculiarity of wonder is lost. For, as Arendt argued elsewhere, any worded expression of the internal workings of the mind is but a metaphor - a representation which categorically differs from what is represented. ${ }^{4}$ For wonder this means that, once channelled through speech, its insight loses generality and becomes an opinion-doxa (from the Greek doke moi - "it appears to me"): the expression of how things appear to me, through my choice of metaphors. ${ }^{5}$

This characterisation of wonder as thaumadzein translates into a profound tension between philosophy and politics. Firstly, Arendt argues that, starting from Socrates, wonder has been portrayed as the defining experience of philosophy. For Arendt this means that philosophy not only begins but also ends with wonderfor, given the unspeakable nature of this pathos, wonder can legitimately lead only to its own perpetuation. ${ }^{6}$ However, politics is - as Arendt would have it - the realm of speech and action, which also includes acting through speaking. Moreover, it seems that it is opinions that constitute the specifically political form of speech. For words and deeds allow citizens to appear to each other, the political realm being "the public space of appearance". ${ }^{7}$ Thus, doxai emerge as part of the fabric of the political domain - the legitimate way to speak about appearances is to resort to the "it-appears-to-me". The life of a citizen is, then, the exact opposite of the life of a philosopher, committed as the latter is to the speechless and passive experience of wonder. Secondly, however, Arendt emphasises that the difference between a philosopher and a citizen does not consist in the mere ability to feel wonder. She insists that the pathos itself is common to all people. What distinguishes a philosopher is the willingness to endure wonder without formulating doxai "on matters about which man cannot hold opinions". ${ }^{8}$

Thus, it might seem that philosophy and politics are completely incompatible, linked to different dimensions of reality. Politics is the realm of active - and therefore plural and changeable - appearances which are processed through opinions, whereas philosophy passively receives ultimate ontological truths. This would suggest that the very idea of "political philosophy" is a contradiction in terms. And yet, as Arendt observes, there is one notable counterargument to this pessimistic

\footnotetext{
${ }^{2}$ H. Arendt, "Philosophy and Politics", Social Research 57 [1] (1990), p. 97.

${ }^{3}$ Ibid., pp. 97-98.

${ }^{4}$ H. Arendt, The Life of the Mind, San Diego-New York-London 1978, 1977 [1971], pp. 30-31, $98-110$.

${ }^{5}$ H. Arendt, "Philosophy and Politics", p. 99.

${ }^{6}$ Ibid., p. 97-99.

${ }^{7}$ H. Arendt, The Human Condition [HC], Chicago-London 1998 (1958), p. 199. Compare also: ibid., pp. 175-247.

${ }^{8}$ H. Arendt, "Philosophy and Politics", p. 99.
} 
conclusion - namely, Socrates, the wonderer, himself. After all, Socrates was both a philosopher and a committed citizen. "He, too", Arendt noticed, arrive[d] at his own doxa", but what distinguished him from his citizens was "that he remain[ed] always ready to endure the pathos of wonder and thereby avoid[ed] the dogmatism of mere opinion holders". ${ }^{9}$ As such, Socrates constitutes not so much an exception to the rule as an example to follow. For, if - as Arendt argues - politics as the space of appearance is at the same time the space of opinions, the ability to take the latter for what they are (i.e. opinions) does seem to require the ability to wonder. It is only against the background of wonder that we can recognise doxai as doxai, instead of dogmatically mistaking them for ultimate truths. Thus, while potentially anti-political, wonder is also necessary - if insufficient - to the possibility of genuine politics.

\section{Lessons from Arendt}

Although Arendt's juxtaposition of wonder and politics draws on the assumptions specific to her philosophy, it also offers several more general insights that I would like to use as the guidelines for my argument. Firstly, while I will not address the link between wonder and philosophy, what I would like to retain from Arendt's interpretation of thaumadzein is the connection between wonder and the sense of the incompleteness of any form of articulate cognition. Wonder puts us in touch with the excess of meaning - the ability to wonder involves the recognition that there is always something more than what we (and each of us) can express at a given moment. Secondly, I borrow from Arendt the idea that politics is the realm in which the non-finality of human judgments is not only accepted but also celebrated. Although this assumption by no means provides a full definition of politics (nor is it its unique feature ${ }^{10}$ ), I take it to be a constitutive element of the political realm. Politics develops against the background of and in reference to the excess of senses. As such, it does seem to require the capacity to wonder. Thirdly, however, Arendt argued that opinions (as the products of actively judging an "it-appears-to-me") and wonder (as a passive pathos) are two distinct phenomena. Though strictly related - wonder being the necessary condition of recognising doxai as doxai - they belong to two different categories. The fundamental theoretical challenge is, thus, the question of how to approach the tension between the two. On the one hand, the friction is productive: opinions will not freeze into dogmas as long as we retain the ability to wonder. On the other, wonder can undermine the very idea of committing oneself to opinions: for what could possibly be the criterion of distinguishing between valid and invalid doxai, given that none of them is final anyway? It is worth noticing that this challenge amounts to reconciling two

${ }^{9}$ Ibid., p. 101.

${ }^{10}$ When, in what follows, I apply aesthetic categories to politics, I draw precisely on this specificity of the latter. Arguably, aesthetics would be more readily associated with open-ended interpretations than politics. Thus, my sketchy concept of politics implicitly involves the claim about its affinity with aesthetics. 
of the common uses of the term "wonder" discussed in the introduction-wonder as an emotion and as an act of judging.

\section{The beautiful and the sublime, bios and dzoe}

To determine how the gap between wonder and doxai can be bridged without the productive tension between the two being annihilated, I would like to introduce two additional Arendtian motifs that have not been mentioned so far. These are, firstly, Arendt's observations on the nature of judgment: arguably, to explicate the relationship between wondering and judging, we should have a rough idea of what the latter involves. Although this is a vexed issue, ${ }^{11}$ what does seem to be certain is that Arendt strongly drew on Kant's Third Critique. What I will call "the Arendtian ${ }^{12}$ account of judgment" is the approach that uses the following elements of Kant's model of taste: the idea that judgments should express an individual perspective and yet present it in a sharable ("universally communicable") manner ${ }^{13}$ the reflective nature of judgment (meaning that judgment is not deduced from a prior concept but instead captures the universal moment in the judged particular) ${ }^{14}$ and the related exemplary type of validity (the particular is presented as an example to follow, rather than the complete and final instantiation of the concept which it exemplifies); ${ }^{15}$ and the possibility of expanding concepts through judgments about their new examples (each particular, judged to be an example of a concept, adds a new dimension to this category). ${ }^{16}$ Thus understood, judgment is a quintessentially political faculty in Arendt's sense: ${ }^{17}$ it yields doxai based on such standards of validity that allow for their non-finality and perspectivity.

However, for Kant - to revert to the original theory-judgment of taste does not cover the entirety of what we would now call the aesthetic realm. Taste responds to the beautiful, whereby the object is perceived as bounded and purpo-

11 See, e.g. Richard Bernstein's (Philosophical Profiles, Philadelphia 1986, pp. 221-237) and Ronald Beiner's ("Hannah Arendt on Judging", [in:] H. Arendt, Lectures on Kant's Political Philosophy, Chicago 1992, pp. 89-156) papers for the analyses of possible inconsistencies in Arendt's approach.

${ }^{12}$ I describe this approach as "Arendtian" rather than "Arendt's" because I am interested in a model that can be deduced from her philosophy, whether or not it is the exact reconstruction of Arendt's own views on judgment. My reading of the Arendtian approach has been inspired by Linda M.G. Zerilli's interpretation of Arendt (see: L.M.G. Zerilli, A Democratic Theory of Judgement, Chicago-London 2016 and Feminism and the Abyss of Freedom, Chicago-London 2005).

${ }^{13}$ I. Kant, The Critique of Judgment, transl. W.S. Pluhar, Indianapolis-Cambridge 1987, § 40, pp. $159-162$.

${ }^{14}$ Ibid., "Introduction", IV, pp. 18-20.

${ }^{15}$ Compare: H. Arendt, "Imagination", [in:] eadem, Lectures on Kant's Political Philosophy, pp. 8485.

${ }^{16}$ I. Kant, The Critique of Judgment, $\S 49$, pp. 181-188.

17 At this point, I follow Linda M.G. Zerilli's interpretation of Arendt's account judgment. Zerilli argues that for Arendt judgment as such is a political faculty, rather than there being a specifically political genre of judgment (L.M.G. Zerilli, A Democratic Theory, pp. 6-10). 
sive, and so "as it were predetermined for our power of judgment". ${ }^{18}$ This aesthetic category is contrasted with the sublime, which carries with it the sense of the unboundedness and formlessness of the object and, therefore, "may indeed appear, in its form, counterpurposive to our judgment". ${ }^{19}$ Interestingly, Kant linked these two aesthetic concepts to two different ways of extending the sense of vitality: whereas the beautiful "carr[ies] with it directly a feeling of life's being furthered", the sublime causes "a momentary inhibition of the vital forces followed immediately by an outpouring of them that is all the stronger". ${ }^{20}$ Consequently, the two experiences are "processed" differently: "the outpour" of vital forces incited by purposeless sublimity can only be mastered by making the "subjectively purposive [...] use" of the object, ${ }^{21}$ while the "furtherance of life" evoked by the beautiful becomes the subject of intersubjectively exchanged judgment of taste. ${ }^{22}$ Thus, somewhat improvising on Kant's original theory, the sublime and the beautiful could represent two attempts at making the excess of life comprehensible: in the former case, the surplus of vitality initially seems overwhelming and is later processed through an individual effort, in the latter - the response is smoother and occurs intersubjectively.

The beautiful/sublime distinction and its link to vitality provide the bridge to the other Arendtian motif that I would like to introduce. Namely, Arendt's famous analyses of the modern "rise of the social" have inspired the ongoing debates about the relationship between dzoe (the natural life) and bios (an individualised life) in (Western) political philosophy. Arendt argued that modern mass societies publicise the natural life, treating their members as mere specimens of a population subject to inevitable life necessities. This development is coeval with the demise of the political realm, for it is only politics - Arendt insisted - that allows human beings to create their own, unique biographies (thus, for humans bios is always bios politikos). ${ }^{23}$ The oppressive potential of the publicising of $d z o e$ was further studied by Michel Foucault in his analyses of biopolitics and biopower. However, Foucault complicated the picture by showing how biopower permeates bodies, moulding them into the subjects of political power. Thus, we could say that a specific bios - a particular political way of life - is inseparable from and complemented by a transformation of $d z o e$. Giorgio Agamben goes as far as to argue that the very separation between bios and dzoe is a political achievement, inherent in Western politics and Western metaphysics alike. Bios can develop only once the realm of dzoe has been designated and excluded from the political community - therefore,

\footnotetext{
${ }^{18}$ I. Kant, The Critique of Judgment, $\S 23$, pp. 98-99.

${ }^{19}$ Ibid., p. 99.

${ }^{20}$ Ibid., p. 98.

${ }^{21}$ Ibid., § 30, p. 142. Italics in the original.

22 "For the beautiful in nature we must seek a basis outside ourselves, but for the sublime a basis merely within ourselves and in the way of thinking that introduces sublimity into our presentation of nature" (ibid., § 23, p. 100).

${ }^{23}$ H. Arendt, $H C$, esp. pp. 22-49, 96-101.
} 
politics, defined as it is by the opposition of the two, necessarily establishes exclusion as its own foundation. ${ }^{24}$

Undoubtedly, then, the bios/dzoe distinction opens up a vast terrain of foundational questions in political philosophy (and metaphysics). However, I would like to narrow them down to the following issues. Firstly, I assume that bios and $d z o e$ constitute two dimensions of life or - to use Arendt's language - two ways in which life can appear: in the former case, life is an individualised unit with a beginning and an end, and is at least to some extent subject to choice and conscious creation; in the latter, life is a supra-individual natural process in which all living organisms are embedded. Secondly, the relation between the two could be described as that of mutual transcendence. That is to say, the condition of bios allows us to go beyond the set determinants of $d z o e$; at the same time, no bios can ever become the full representation of $d z o e$ - the final individual instantiation of what is natural for beings of a given kind. Finally, I retain the (perhaps specifically Western) link between the bios/dzoe opposition and the political constitution of subjectivity. For now I assume that (and later suggest possible reasons why) subjectivity - the idea of what it means to live a bios as an individualised life - develops politically and as such presupposes the distinction from, but also the background of, dzoe. Rather than casting it off entirely, my intention will be to see how far the tension between the two can be eased off without the productive potential of their mutual transcendence being lost.

At this point, the concepts of the beautiful and the sublime can perform their "bridging" function, bringing together the bios/dzoe dilemma and the Arendtian account of judgment. On the one hand, I have suggested that the experiences of the beautiful and the sublime could represent two responses to the excessive richness of life: the recognition that there will always be more to being alive than what we already know. The way I have presented it, the bios/dzoe distinction reflects precisely this type of insight, inasmuch as it corresponds to the mutual transcendence of the two dimensions of life. On the other hand, I have adopted the Arendtian approach to argue that it is the beauty-directed judgment of taste that functions as the model for political speech (doxai), whereby the excess of meanings is channelled in a manner that is neither reductive nor incomprehensible. Putting these two together, it could be concluded that the politically foundational surplus of senses pertains to the bios/dzoe tension as to the background against which subjectivity develops. Thus, the constitution of subjectivity has to be political, inasmuch as it is only through doxai - as the political mode of speech - that the excessive richness of human forms of life can be captured..$^{25}$

${ }^{24}$ G. Agamben, Homo Sacer. Sovereign Power and Bare Life, transl. D. Heller-Roazen, Stanford 1998, pp. 1-12.

${ }^{25}$ See also Alessandro Ferrara's ingenious political interpretation of Kant's model of taste. Ferrara, too, emphasises the element of "the furtherance of life" (idem, The Force of the Example. Explorations in the Paradigm of Judgment, New York-Chichester 2008, pp. 30-34) and links it to Christine Korsgaard's concept of "the description under which we value ourselves". "The life" that is being "furthered" (or: extended) through reflective judgment is the account of human flourishing accepted 
Where does wonder fit into this picture? As the general sensitivity to the excess of meanings, wonder seems to be presupposed by the more specific ability to reflect on the inexhaustibility of human forms of life. At the same time, as Arendt insisted, wonder pushes towards doubt and non-commitment. Hence, showing how it could make a constructive political contribution requires two major steps: linking wonder to judgment modelled after taste (the aesthetic moment) and introducing the bios/dzoe distinction as its possible object (the environmental moment).

\section{Nussbaum - the peculiar emotion of wonder}

As I have suggested, I would like to develop my argument with the help of the insights of two philosophers-Martha C. Nussbaum and Jeremy Bendik-Keymer. The former sketched the account of wonder which is now being creatively developed by the latter - both of the approaches, I will argue, being relevant to the challenge set by Arendt.

The category of wonder may seem marginal to Nussbaum's philosophical project, whose core is defined by the enquires about social justice (articulated in the language of the capability approach) and the revision of the foundations of liberalism (in the spirit of John Rawls's political liberalism). However, these key areas of Nussbaum's research are linked by her commitment to civic education - the assumption that institutional solutions have to be complemented by appropriate attitudes of individuals. It is in this context that she develops her philosophical theory of emotions, in which wonder occupies a special position. The resulting approach is relevant to my argument for four reasons.

Firstly, Nussbaum's decision to classify wonder as an emotion introduces an interesting theoretical solution. Although it may seem that, in this respect, Nussbaum does not divert from Arendt, her concept of an emotion is very much different from Arendt's pathos. Far from being merely passive states to be endured, emotions on Nussbaum's (neo-Stoic, as she calls it) account express judgments of a special type. ${ }^{26}$ Namely, they "are forms of evaluative judgment that ascribe to certain things and persons outside a person's own control great importance for the person's own flourishing". ${ }^{27}$ As such, emotions crucially involve an element of active assessment. At the same time, as long as Nussbaum calls them "emotions"-rather than unspecified "judgment"-she seems committed to retaining their affective, passive dimension as well. "Emotions [...] are acknowledgments of neediness and lack of self-sufficiency", ${ }^{28}$ through which we allow ourselves to be touched by external factors. Hence, if wonder is an emotion in this sense, it combines the elements of judging and the elements of feeling.

in a political community. Ferrara then goes on to argue that reflective judgment thus understood is an integral part of reasonableness in the sense of John Rawls's political liberalism (ibid., pp. 72-79).

${ }^{26}$ M.C. Nussbaum, Upheavals of Thought. The Intelligence of Emotions, New York 2008 (2001), pp. 19-88. See also eadem, The Therapy of Desire. Theory and Practice in Hellenistic Ethics, Princeton-Oxford 2009 (1994) for Nussbaum's presentation of the philosophical sources of her approach.

27 M.C. Nussbaum, Upheavals, p. 22.

28 Ibid. 
The hybridity of Nussbaum's approach did not convince all commentators. Several critics have argued that Nussbaum fails to synthesise the intellectual and the affective aspects of emotions, sacrificing the latter for the former. ${ }^{29}$ Most relevantly to the political implications of Nussbaum's approach, Veronica Vasterling has accused the American philosopher of "methodological solipsism". For Nussbaum, Vasterling argues, emotions reflect the perspective of an atomised individual, who evaluates her surroundings against the background of her understanding of the good. Although they express the sense of dependence on external factors, the life plan from which they are deduced seems to be given a priori. ${ }^{30}$ The reason why I take this criticism to be relevant to my argument is that it raises doubts as to whether the account of subjectivity linked to Nussbaum's theory of emotions is political at all. Nussbaumian individuals let themselves be externally affected only in the process of pursuing rather than defining their ideas of the good. Though porous, the visions of flourishing on which they act do not seem to be open-ended.

Yet, confronted with Vasterling's charge, wonder only appears all the more pertinent. This is because, as Nussbaum openly admits, this emotion constitutes an exception to her overall approach. "Wonder", Nussbaum says, is "as non-eudaimonistic as an emotion can be": ${ }^{31}$ rather than stemming from a predetermined idea of the good, it "responds to the pull of the object", whereby "the subject is maximally aware of the value of the object, and only minimally aware, if at all, of its relationship to her own plans". ${ }^{32}$ This is not to say that wonder is irrelevant to the individual's understanding of her flourishing - quite to the contrary, one's life plan can be transformed through the inclusion of a newly discovered wonderful object. Thus, wonder creates a gap in Nussbaum's account of subjectivity: no wondering individual can ever be sure that she has a complete understanding of her good. At the same time, wonder allows her to make sense of the novelties that she comes across by inspiring her to assimilate them into her vision of flourishing. And given that the movement between open-endedness and comprehensibility in the reflection on the possible forms of human subjectivity is what I take to be the essence of politics, it could be argued that wonder introduces a (proto- ?) ) $^{33}$ political element into Nussbaum's model of subjectivity. By the same token, the second important element of Nussbaum's account of wonder would be its potential political relevance. Unlike for Arendt, there is no apparent tension between wonder and politics in Nussbaum's theory. To the contrary, it seems that wonder gives her approach a political twist.

${ }^{29}$ See, e.g., Ch. Altieri, The Particulars of Rapture. An Aesthetics of the Affects, Ithaca-London 2003, pp. 158-168; R. Crisp, "Compassion and Beyond", Ethical Theory and Moral Practice 11 [3] (2007 [2008]), pp. 233-246, https://doi.org/10.1007/s10677-008-9114-x.

${ }^{30}$ Interestingly enough, Vasterling juxtaposes Nussbaum's approach with that of Arendt's. See: V. Vasterling, "Cognitive Theory and Phenomenology in Arendt's and Nussbaum's Work on Narrative", Human Studies 30 (2007), pp. 79-95, https://doi.org/ 10.1007/s10746-007-9050-0, in particular: pp. 88-94.

31 M.C. Nussbaum, Upheavals, p. 55.

32 Ibid., p. 54.

${ }^{33}$ See the next section for the doubts related to the political credentials of Nussbaum's approach. 
Interestingly enough, the exceptional-non-eudaimonistic - status of wonder (reflected by its politicising influence) is linked to its systematic importance. Nussbaum emphasises that, even if objects of emotions are assessed in terms of their relevance to the individual's flourishing, they are nonetheless perceived as inherently valuable. In other words, emotions are the recognitions that certain things or persons have intrinsic worth and as such matter to the person's flourishing ("This is why", says Nussbaum, "in the negative cases, they are felt as tearing the self apart"). ${ }^{34}$ But since it is wonder that, as a non-eudaimonistic emotion, grasps the inherent importance of the object, this attitude is either closely connected to or even included in other benign emotions. ${ }^{35}$ Thus, by virtue of its very exceptionality, wonder also plays a systematic role in Nussbaum's theory. The link between these two - only seemingly paradoxical - functions of wonder is provided by its third important feature, i.e. its aesthetic character. For it can be observed that the non-eudaimonistic, but eudaimonia-transforming, structure of wonder resembles the Arendtian model of judgment inspired by Kant's model of taste. Wonder is not deduced from a definite concept of flourishing and in this sense is reflective. As such, it does not violate the individual's idea of the good but rather has the potential to inspire its reformulation. Thus, of the two aesthetic approaches to transcendence, wonder is akin to the beautiful rather than the sublime ${ }^{36}$ - the conclusion corroborated by Nussbaum's distinction between wonder and awe. ${ }^{37}$

This general characteristic allows Nussbaum to detect the workings of wonder in the appreciation of a specific inherently valuable item-namely, human dignity. ${ }^{38}$ Since Nussbaum follows Kant in defining the latter as "the principle of each person as an end, ${ }^{39}$ wonder emerges as the conditio sine qua non of recognising the other person's dignity: it is through non-eudaimonistic wonder that we

${ }^{34}$ M.C. Nussbaum, Upheavals, p. 33. Compare: ibid., pp. 30-32.

35 Ibid., pp. 54, 321-322.

${ }^{36}$ My main point is that, on Nussbaum's account, wonder has the structure of the aesthetic experience of the beautiful (i.e. it represents an aesthetic type of reasoning). Apart from that, Nussbaum links wonder to the actual perception of artworks as well (ibid., pp. 277-278). This is especially important in her account of the moral psychology of liberalism, which crucially involves the educational role of arts and the humanities (see: M.C. Nussbaum, Political Emotions, Why Love Matters for Justice, Cambridge-Massachusetts-London 2013; Not for Profit. Why Democracy Needs Humanities, Princeton-Oxford 2010).

37 "Wonder and awe are akin, but distinct: wonder is outward-moving, exuberant, whereas awe is linked with bending, or making oneself small. In wonder I want to leap or run, in awe to kneel" (M.C. Nussbaum, Upheavals, p. 54, footnote).

38 Therefore, Nussbaum seems to use the category of wonder in two senses: as a general capacity to grasp the inherent worth of an object and as the affirmation of human dignity as a specific type of an autonomous value. Although this duality could be criticised as incoherence, I assume that dignitydirected wonder is a species of wonder in general. Thus, wonder need not be directed at human dignity, but human dignity cannot be grasped without wonder (compare also J. Bendik-Keymer, "The Reasonableness of Wonder", Journal of Human Development and Capabilities 18 [3] (2017), pp. 338-342, https://doi.org/10.1080/19452829.2017.1342385 on the possible levels of generality in Nussbaum's concept of wonder).

${ }^{39}$ M.C. Nussbaum, Women and Human Development. The Capabilities Approach, New York 2000, p. 74. Italics in the original. 
attest to the non-instrumental value of another human being. ${ }^{40}$ At the same time, Nussbaum links the Kantian moment of non-instrumentality to the Aristotelian (as she describes it) account of the human condition that gives equal weight to human rationality and animality, ${ }^{41}$ with sociability and politicality not being opposed to each other. ${ }^{42}$ Hence, Nussbaum's Aristotelian-Kantian concept of dignity can be said to blur the distinction between dzoe and bios: ${ }^{43}$ bodiliness is not in tension with individuality and there is no radical distinction between different types of relating (the social and the political); at the same time, qualitatively diverse aspects of the human life are given equal value. ${ }^{44}$ Nussbaum thus offers an account of subjectivity which eases off the tension between dzoe and bios. Now, if wonder is the type of reasoning through which such subjectivity is appreciated and wonder also introduces a political element into Nussbaum's project, then it would appear that wonder could also endow the bios/dzoe-blurring account of subjectivity with political relevance. This is the fourth element of Nussbaum's approach that I would like to keep.

\section{Nussbaum's approach - further questions}

The four important aspects of Nussbaum's account of wonder are thus as follows: the affective-intellectual nature of wonder (based on Nussbaum's theory of emotions); the politicisation of wonder (related to its politicising influence on Nussbaum's account of subjectivity); the aesthetic structure of wonder and its affinity to the experience of the beautiful; wonder as the ability to go beyond the bios/ dzoe distinction in the appreciation of human dignity. These assumptions provide a good framework for a theory of wonder as a political category. At the same time, they leave us with several questions, which will have to be addressed if a robust political account of wonder is to be developed.

Firstly, the allegedly double, affective-intellectual, character of wonder could be criticised from the angle opposite to the one discussed so far. That is to say: whereas wonder may not be deficient in receptivity, it can come out as not intellectual enough. Granted, if wonder is an emotion and emotions - says Nussbaum - are judgment, then wonder is a judgment too. The question is, however: what judgment could it actually expresses? On Nussbaum's account, wonder has the air of

${ }^{40}$ M.C. Nussbaum, Upheavals, pp. 206-224; eadem, Political Emotions, pp. 168-182.

${ }^{41}$ M.C. Nussbaum, Frontiers of Justice Disability, Nationality, Species Membership, CambridgeLondon 2007 (2006), pp. 159-160.

${ }^{42}$ M.C. Nussbaum, "Aristotle on Human Nature and the Foundations of Ethics", [in:] World, Mind, and Ethics: Essays on the Ethical Philosophy of Bernard Williams, J.E.J. Altham, R. Harrison (eds.), Cambridge 1995, esp. pp. 102-110.

43 See: Nussbaum's linguistic analysis in which she questions the philological basis for starkly distinguishing between the two (ibid., pp. 115-116).

${ }^{44}$ Nussbaum's account of subjectivity is expressed in terms of her ten-element catalogue of central human capabilities (see, e.g., M.C. Nussbaum, Upheavals, pp. 416-418). The list includes the capability of "the political control over one's environment" and, as a whole, is infused with the "architectonic" capability of affiliation. Thus, political capabilities are construed as a subcategory of overall human sociability. 
an individual revelation: the recognition that a previously unappreciated item - or, more importantly, a person - is inherently valuable and therefore deserves to be included into my idea of flourishing. But there is something mysterious to this process: why should this particular person incite my wonder? While surprise and idiosyncrasy are undoubtedly constitutive of wonder, its political application should consist precisely in the balancing between the two and an intersubjective standard: arguably, this is what it would take to affirm the validity of doxai as doxai.

Therefore and secondly, the political transformation of wonder in Nussbaum's approach is yet incomplete. Wonder shakes individuals out of their cosy ideas of personal flourishing, thereby functioning as a propaedeutic political experience: it confronts individuals with the richness of perspectives (doxai), all of which are worthy of respect, yet none of which is final. At the same time, wonder plays an important part in the justification of Nussbaum's capabilities catalogue: inasmuch as the list specifies the basic conditions of a dignified human existence and dignity is appreciated through wonder, the process of formulating the catalogue seems to be driven by wonder at human dignity. ${ }^{45}$ What Nussbaum does not explain, however, is how these two levels of wonder - as an individual revelation and as an element of political reasoning - can be linked. How can wonder at the particularity of a specific person be translated into wonder at her exemplarity, whereby the person's uniqueness is perceived as potentially relevant to the redefinition of the shared understanding of the human life? It is also worth noticing that, thirdly, the incomplete politicisation of wonder corresponds to its incomplete aestheticization. The main objective of Kant's account of the judgment of the beautiful - to which, I have argued, wonder bears resemblance - is to show how subjective experiences of the beautiful can nonetheless be communicated and intersubjectively evaluated. This challenge remains unresolved for Nussbaum.

Finally, one might ponder on the blurring of the bios/dzoe distinction involved in Nussbaum's concept of human dignity. She allows for animality (dzoe) in her understanding of an individualised human life (bios) - what needs to be clarified, however, is how the two are related to each other. Are they given equal weight or is dzoe included into bios, constituting the dzoe of bios, so to speak? The latter interpretation seems to be substantiated by Nussbaum's commitment to individualism, only amplified by the ambiguity related to the dual sense of wonder. In that case, the tension between bios and dzoe would be reduced as a result of dzoe being "swallowed" by bios. And yet, I have assumed that the political constitution of subjectivity rests on the productive use of the mutual frictions between the two, rather than on their resolution. Doubts similar to these seems to have been behind Bendik-Keymer's reinterpretation of Nussbaum's approach as well. Therefore, I will now move on to his observations.

${ }^{45}$ M.C. Nussbaum, Women, pp. 72-73. Compare also Bendik-Keymer's emphasis on the link between wonder and Nussbaum's catalogue: J. Bendik-Keymer, "The Reasonableness of Wonder", pp. 338-339. 


\section{Wonder revised}

I would like to point to two important contributions that Bendik-Keymer has made in his reworking of Nussbaum's ideas. They not only help address the questions entailed by Nussbaum's approach, but are also relevant to the political status of wonder in general. Therefore, the review of Bendik-Keymer's observations will allow me to return to Arendt's position in the next step, and so to conclude the paper.

\section{The bios/dzoe-centrism of wonder}

The first of Bendik-Keymer's important innovations has been motivated by the environmental implications of Nussbaum's approach. Insisting that human beings possess dignity as animals - rather than in spite of or in abstraction from their animality - Nussbaum concludes that dignity is not an exclusively human quality. Instead, it can be attributed to "any complex natural organism". ${ }^{46}$ As it is wonder that captures human dignity, the same capability recognises other forms of this value: "there is something wonderful and wonder-inspiring in all complex forms of life in nature" 47 and so we should "accord respect to animals and recognise their dignity". 48

Taking a close look at these observations, Bendik-Keymer suggests that the rationale behind Nussbaum's call for respecting "all natural organisms" is the fact that they possess a teleology - their lives unfold gradually and as such can be supported (but also harmed) in the process; their activities are arranged in patterns adequate for the achievement of their specific good. ${ }^{49}$ But if the core of dignity is defined so generally, human dignity is but its one category and can only be appreciated against this broader background. In other words, Nussbaum's "outlook" is "biocentic" subspecies of wonder begins with the recognition of the value of "living dignity", into which respect for human dignity should be integrated, rather being extended to other living organisms. ${ }^{51}$

This bios/dzoe-centric reorientation of wonder is important for several reasons. It clarifies Nussbaum's approach and makes it more coherent - the conclusion con-

${ }^{46}$ M.C. Nussbaum, Frontiers, p. 94.

47 Ibid., p. 347.

${ }^{48}$ Ibid., p. 94.

49 J. Bendik-Keymer "From Humans to All of Life: Nussbaum's Transformation of Dignity", [in:] Capabilities, Gender, Equality. Towards Fundamental Entitlements, F. Comim, M.C. Nussbaum (eds.), Cambridge 2014, pp. 178-179. I have deliberately used the non-intentional language while sketching Bendik-Keymer's (interpretation of Nussbaum's) concept of teleology. This is because-as I show below - he insists that dignity should also be ascribed to non-individualised living beings, who cannot be said to deliberately strive for their good. Perhaps, then, a better word to describe such purposeful, either intentional or non-intentional, organisation would be "teleonomy".

${ }^{50}$ Ibid., pp. 176-178.

51 J. Bendik-Keymer, "The Reasonableness of Wonder", pp. 337-338. 
firmed by Nussbaum's endorsement of Bendik-Keymer's arguments. ${ }^{52}$ Moreover, it increases the environmental potential of Nussbaumian wonder, pushing it beyond anthropocentrism and anthropomorphism. ${ }^{53}$ What I am most interested in, however, are the potential political implications of the "bios/dzoe-ification" of wonder. The reason why I am insisting on using this clumsy term is that Bendik-Keymer's interpretation of wonder draws on the two dimensions of life much more decidedly than Nussbaum's original formulation does. On the one hand, he argues that living dignity to which wonder responds does not necessarily take a bio(s)graphical form. The teleological - or perhaps: teleonomic ${ }^{54}$ _organisation can be ascribed to beings whose lives do not develop in individualised units (such as ants or termites, let alone plants). ${ }^{55}$ Thus, inasmuch as bios as a personalised life with a closed narrative structure does not exhaust all possible types of living dignity, the latter seems to cover the terrain of $d z o e$ as well. On the other hand, human dignity is perceived neither in opposition to nor even as the model for other forms of living dignity. Instead, wonder at human dignity stems from wonder at living dignity, the latter providing the rationale for the former. Moreover, Bendik-Keymer argues that it is only against the background of undifferentiated living dignity - both individualised and non-individualised - that the diversity of bioi can be appreciated. This is because, inasmuch as it brackets the inevitability of individualisation, wonder at living dignity at the same time unlocks the possibility of reflecting on what an individualised life means for humans. The bios/dzoe-centric wonder prevents bios from being trapped in one specific form and facilitates its becoming a matter of genuine choice. ${ }^{56}$

Interestingly enough, Bendik-Keymer observes that Nussbaum's association of dignity with striving opens the possibility of ascribing this value to non-naturalmost relevantly: artificial (AI $)^{57}$ - entities as well. After all, a robot or a cyborg could be "as complex as many things in nature and [act] on its own accord" implies that "being of a living kind is sufficient for having dignity but it is not

${ }^{52}$ M.C. Nussbaum, "Human Capabilities and Animal Lives. Conflict, Wonder, Law. A Symposium", Journal of Human Development and Capabilities 18 [3] (2017), pp. 319-320, https://doi.org/1. 1080/19452829.2017.1342382.

53 J. Bendik-Keymer, "The Politics of Wonder. Extending the Capabilities Approach to Other Species in the Context of Mass Extinction", [in:] The Cambridge Hanbook of Capabilities, M. Qizilbash et al. (eds.) - forthcoming. Available at: https://drive.google.com/file/d/1S6WQAvXJO-uKlpAvv0xm4uLqjmjZNdLd/view (accessed: 4.04.2020).

54 See footnote 49 .

55 J. Bendik-Keymer, "The Politics of Wonder", passim.

56 J. Bendik-Keymer, "The Reasonableness of Wonder", pp. 347-351.

57 The category of non-natural beings includes supernatural beings as well. As Bendik-Keymer observes, Nussbaum "implies" that God is endowed with dignity in her understanding of the term (J. Bendik-Keymer, "From Humans to All of Life", pp. 179-180; M.C. Nussbaum Frontiers, p. 362). This leads to an interesting conclusion: for inasmuch as dignity essentially involves a developmental tendency directed at the being's specific good, it seems to presuppose incompleteness (the good is still to be achieved). Therefore, dignity thus conceived would somewhat qualify the "supernaturalness" of God.

${ }^{58}$ J. Bendik-Keymer, "From Humans to All of Life", p. 180. Compare: M.C. Nussbaum, Frontiers, p. 362 . 
necessary"). ${ }^{59}$ If we allow that artificiality is the extreme pole of bios -inasmuch as the latter represents a life open to individual creation and artificiality corresponds to the condition of pure constructivism - the emerging reach of dignity trespasses the bios/dzoe distinction. In the outlook offered by Bendik-Keymer, the two dimensions of life constantly flow one into the other: the confrontation with the undifferentiated realm of living dignity fuels the reflection on what it means to be a bios - an individualised being; at the same time, bios strikes back, so to speak, offering to enrich the spectrum of dignified entities with artificial exemplars.

This exchange is facilitated by wonder, whose dignity-directed subspecies is sensitive to any type of a teleonomic arrangement. Therefore, if - as I have assumed-subjectivity emerges out of the political push and pull between bios and $d z o e$, then wonder plays at least an introductory function in this process: wonder allows us to capture the fluidity of the boundaries between the two without reducing one to the other. Yet, Bendik-Keymer's observations suggest that the political relevance of wonder goes beyond that: wonder not only paves the way for the political constitution of subjectivity but also actively participates in it. This takes me to the other important shift in the Nussbaumian category that Bendik-Keymer offers.

\section{Wonder as an operation}

It is important to observe how the bio/dzoe-centralisation of wonder bridges the gap between its personal and public use that Nussbaum seems to have left. As a result of the refocusing on living dignity, the moment of an individual revelation (which featured so prominently in Nussbaum's account) gives way to the perception of the richness of life. Thus understood, wonder is necessarily comparative: the element of surprise pertains not so much to my own idea of flourishing as to the broader concept of living dignity, the particular source of wonder being its unprecedented exemplar. Against this bios/dzoe-centric background, reflection on the human type of living dignity can legitimately occur. Wonder, says BendikKeymer, "open[s] up [...] the space of consideration", that is - of "moral respect for who is speaking and thoughtful attention to what is being discussed". 60 Thus, the respectful overview of the diverse exemplars of human living dignity allows us to validly pinpoint the common features of human subjectivity. ${ }^{61}$

Bendik-Keymer clearly sees this process of defining subjectivity as political: he links "the space of consideration" to "the space of speaking in democracy"; 62 more specifically, he argues that wonder could be seen as - at least - a helpful addition to John Rawls's attempts at legitimising liberalism (in both of its varieties: the contractualist one from $A$ Theory of Justice and the later reasonable justifica-

${ }^{59}$ J. Bendik-Keymer, "From Humans to All of Life", p. 180. Italics in the original.

60 J. Bendik-Keymer, "The Reasonableness of Wonder", p. 347. Italics in the original.

61 "The way I put this is to say that what is sought is a space between different conceptions of striving that allows the people reasoning together to understand the conditions of their striving across different ways of striving" (ibid., p. 349).

62 Ibid., p. 347. 
tion from Political Liberalism); ${ }^{63}$ adopting the language of capabilities, he also points to the relevance of wonder to the meta-capability of capability determination: the ability to collectively define what the most important human capabilities are. ${ }^{64}$ The question is, however: is wonder simply included into the procedure of the political construction of subjectivity, thereby corroborating the presupposed political character of this process? Or does wonder (co-)contribute to its very constitution, thereby justifying the assumption of its political nature? In other words: does comparative wonder become intersubjective when exercised in a predetermined political context? Or is there anything inherently intersubjective about wonder's comparativeness?

When he says that wonder "opens up [emphasis mine] [...] the space of consideration" and argues for its involvement in capability determination, Bendik-Keymer seems to lean to the latter interpretation. This conclusion appears to be linked to the second moment of his reinterpretation of Nussbaum that I would like to emphasise - namely, the idea that wonder should be understood as "an operation". In a recent conference paper, Bendik-Keymer argues that, because of its comparative nature, wonder is essentially something that is performed-it does not have to (though it certainly can) also be felt in the process. Wonder is about assessing the perceived novelty against the background of one's prior experience. ${ }^{65}$ As a result, Bendik-Keymer shifts the meaning of wonder from an emotion to judgment - of the two basic connotations of the term, the latter begins to take precedence.

Still, wonder could be other-directed-responding to the radical difference of other human beings - and yet develop as the exercise of a solitary mind. In other words, the judgment-like operation of comparative wonder in itself does not endow it with an intersubjective character. Perhaps, then, it requires an external stimulation - in the same paper, Bendik-Keymer argues for the importance of social practice art for activating wonder ${ }^{66}$ However, certain formulations that he uses point to the direction of developing intersubjectivity out of the operation of wonder itself.

Notice the following observation: as an operation, "wonder" [...] "is positive tarrying with the negative [...], positioning meaningfulness as more than what is in one's grasp". ${ }^{67}$ It is striking how this description brings together the two opposing poles of Arendt's challenge which started my argument. On the one hand, inasmuch as it addresses "the negative", Bendik-Keymer's wonder resembles Arendt's idea of thaumadzein as the insight into the inexhaustible excess of meaning. On the other, its "positive" potential - the ability to make sense out of the transcendence of sense - links it to judgment as the faculty responsible for formulating valid doxai. Interestingly, the common ground between the two seems to be provided by the account of subjectivity as the object of bios/dzoe-centric wonder. For Bendik-

${ }^{63}$ Ibid., pp. 343-351.

${ }^{64}$ J. Bendik-Keymer, "Wonder, Capability Determination, and Epistemic Inclusion", Human Development and Capability Conference 2018 paper.

65 Ibid., p. 22.

66 Ibid., pp. 25-30.

${ }^{67}$ Ibid., p. 22. Italics in the original. 
Keymer argues that "the power to determine [one's] own life", that is - we might say - to live it as a bios, includes the following elements: subjectivity ("a person's ability to think for themselves"), ${ }^{68}$ agency ("a person's ability to decide and to act on their own courses of action") and interpersonal being ("a person's ability to be social [or not to be] in a way that suits their sense of society"). ${ }^{69}$ These three dimensions resemble, in turn, Kant's maxims of thinking - unprejudiced ("think for oneself"), consistent ("to always think consistently"), ${ }^{70}$ broadened ("to think from the standpoint of everyone else") — that can be taken to define the functioning of taste as sensus communis. ${ }^{71}$ This correspondence seems telling: if reflection on subjectivity should cover the aspects analogical to those which orient the opera-

${ }^{68}$ Bendik-Keymer uses the term "subjectivity" in a narrower sense than I do. In my understanding, the concept could cover all three dimensions that he mentions.

${ }^{69}$ Ibid., p. 12.

70 The analogy between agency, as Bendik-Keymer defines it, and the maxim of consistency may seem strained. Yet, it is important to note that Kant saw the ability to follow this maxim as conditional on the use of the other two ("[this maxim] is hardest to attain and can in fact be attained only after repeated compliance with a combination [emphasis mine] with [the other] two has become a skill", I. Kant, The Critique of Judgment, § 40, pp. 161-162). In other words, we only think consistently provided that we have learnt to think both independently and in resonance with others. Arendt developed this apparent paradox, when she argued that thinking as a solitary activity is coeval with the ability to think with others, inasmuch as the former develops as an internal dialogue between me and myself. This explains the connection between consistency and the other two maxims: it is the experience of the 'built-in' interlocutor that pushes me to struggle for coherence, now understood as internal agreement. But this also allowed Arendt to draw moral consequences from the maxims of thinking-for her (as her famous reflections on Eichmann's trials showed), consistency was the bedrock of moral personality (H. Arendt, "Thinking and Moral Considerations", [in:] eadem, Responsibility and Judgment, New York 2003, p. 159-189). The latter essentially involves the ability to make informed decisions, based on the perception of one's life as a developing narrative (a bios), rather than a set of disjointed acts. It is in this sense - as the core of moral personality - that I believe consistency could be linked to Bendik-Keymer's concept of agency.

${ }^{71}$ I have used the tentative expression "can be taken to define" because Kant's original observations on taste as sensus communis are rather confusing. In $\S 40$ he analyses the ambiguity of the term "common sense" (der Gemeinsinn), where "common" (gemein) can mean both "sharable" and "vulgar" (I have used the following version of the German text: I. Kant, Kritik der Urteilskraft, Leipzig 1922. Available at: https://archive.org/details/kritikderurteils00kantuoft/page/n5, accessed: 24.02.2019). The three maxims are introduced as the maxims of "the common human understanding" (I. Kant, The Critique of Judgment, $\S 40$, p. 160) (des gemeinen Menschenverstandes), the review of which leads Kant to the conclusion that "taste can be called a sensus communis more legitimately than can sound understanding (der gesunde Verstand)" (ibid., p. 161). If "sound understanding" is to be interpreted as the synonym of "common human understanding", the relationship between the three maxims and taste as a sensus communis is not clear. Pluhar's translation hints at the contrast between the maxims and taste ("[Let us compare with this sensus communis] the common human understanding, even though the latter is not being included here as a part of the critique of taste", ibid., p. 160), whereas J.H. Bernard's version reads that the maxims "do not properly come in here, as parts of the Critique of Taste; but yet they may serve to elucidate its fundamental propositions" (I. Kant, The Critique of Judgment, translated with introduction and notes by J.H. Bernard, London 1914, § 40, p. 139. Available at: https://oll.libertyfund.org/titles/kant-the-critique-of-judgement, accessed: 24.02.2019). In the latter case, the maxims would contribute to explaining how taste functions, its claim to being called "a sensus communis" possibly stemming from its ability to meet these standards more fully. Arendt seems to adopt this interpretation - she describes the maxims as "the maxims of sensus communis" and spells out the specificity of taste in their terms (H. Arendt, "Twelfth Lecture", [in:] eadem, Lecture's on Kant's Political 
tion of judgment as a type of sensus communis, then possibly it ought to occur through the medium of this model of intersubjective reasoning. Thus, if the excess of meaning discovered by wonder pertains to the diversity of human living dignity and if the common features of human subjectivity include the same moments as those that define the functioning of the intersubjective faculty of judgment, then the latter emerges as the continuation of wonder.

\section{Conclusion}

My intention in this paper has not been to argue that wonder "does the whole job" in political philosophy, that is - that political philosophy is essentially about wonder (let alone the reverse!). The starting point for my argument was the following combination: Arendt's observations on the complex relationship between wonder and the basis of politics, on the one hand, and Nussbaum's and Bendik-Keymer's specific political interpretations of wonder, on the other. Against this background, I have tried to analyse a possible foundational role of wonder in politics. By way of a conclusion, let me recapitulate the results of this overview.

I have started from the Arendtian vision of politics as the realm of doxai: the area that facilitates perspectival thinking, while also providing standards for its assessment. The relationship of wonder to politics thus understood is ambiguous: inasmuch as it confronts us with the inexhaustible excess of meaning, it both invalidates each particular opinion (doxai) and constitutes the necessary condition for their validation as opinions. Hence, the following question has to be addressed: how to make this wondrous "tarrying with the negative", as Bendik-Keymer would say, productive? In one of the first steps, I have argued that the core content of doxai pertains to the account of human subjectivity, which develops out of the push and pull between bios and dzoe. Hence, political speech is about subjectivity; and likewise, subjectivity can only be spoken about politically, inasmuch as the mode of doxa allows to capture the mutual transcendence of bios and dzoe. Now, however, it could be asked if it is possible to move beyond the circularity when addressing the relationship between politics and subjectivity. In other words, could their mutual dependence be justified, rather than merely affirmed?

I would like to suggest that the interpretation of Nussbaum's and Bendik-Keymer's accounts of wonder offered in this paper can be read as contributions to such justification. That is to say: wonder emerges as the factor that makes reflection on subjectivity political. Nussbaum's emotion of wonder transcends individual horizons and paves the way for the idea of human flourishing being defined in response to different exemplars of human dignity. Yet, I have suggested that, on Nussbaum's interpretation, the connection between the subjective and the intersubjective dimensions of wonder is not yet seamless. Bendik-Keymer's bios/dzoe-ification of wonder opens up the broad horizon of living dignity, implying that a valid account of human subjectivity can only emerge out of the comparisons of specific

Philosophy, pp. 70-72). Since I am most interested in Arendt's political use of Kant's theory, I accept her approach without determining whether it is the most accurate reading of the original formulation. 
instantiations of human living dignity. Moreover, his insistence that wonder is an operation and the similarities between his description of wonder and the Arendtian account of judgment link it to the political standard of reasoning. On the whole, then, Nussbaum's and Bendik-Keymer's observations yield the picture of wonder as a two-horn phenomenon. On the one hand, wonder is hooked to human dignity conceptualised against the background of the bios/dzoe-continuum. On the other, it is linked to political judgment. As such, wonder facilitates the transition from the reflection on subjectivity to political speech, thereby providing a justification of why the excess of meaning spoken about politically should essentially concern human subjectivity.

In this way, my analysis has taken me to the starting point of my argument. Initially contrasted, wonder and doxa as the product of judgment begin to intersect. Still, the exact relationship between wonder and judgment would require further research. I have so far described it only vaguely ("continuation", "link"), not wanting to determine whether wonder actually is judgment or, rather, something "judgment-like"- a propaedeutic exercise, from which judgment takes over. However, I hope to have shown not only that the two do not exclude each other, but also that they operate based on similar principles.

\section{References}

Agamben G., Homo Sacer. Sovereign Power and Bare Life, transl. D. Heller-Roazen, Stanford 1998.

Altieri Ch., The Particulars of Rapture. An Aesthetics of the Affects, Ithaca-London 2003, pp. 158-168.

Arendt H., The Human Condition, second edition, Chicago-London 1998 (1958).

Arendt H., Lectures on Kant's Political Philosophy, Chicago 1992.

Arendt H., The Life of the Mind, San Diego-New York-London 1978, 1977 [1971].

Arendt H., "Philosophy and Politics", Social Research 57 [1] (1990), pp. 73-103.

Bendik-Keymer J., "From Humans to All of Life: Nussbaum's Transformation of Dignity", Capabilities, Gender, Equality: Towards Fundamental Entitlements, F. Comim, M.C, Nussbaum (eds.), Cambridge 2014, pp. 175-191.

Bendik-Keymer J., "The Politics of Wonder. Extending the Capabilities Approach to Other Species in the Context of Mass Extinction", [in:] The Cambridge Hanbook of Capabilities, M. Qizilbash et al. (eds.) —forthcoming. Available at: https://drive. google.com/file/d/1S6WQAvXJO-uKlpAvv0xm4uLqjmjZNdLd/view (accessed: 4.04.2020).

Bendik-Keymer J., "The Reasonableness of Wonder", Journal of Human Development and Capabilities 18 [3] (2017), pp. 337-355, https://doi.org/10.1080/19452829.201 7.1342385 .

Bendik-Keymer J., "Wonder, Capability Determination, and Epistemic Inclusion", Human Development and Capability Conference 2018 paper.

Bernstein R., Philosophical Profiles, Philadelphia 1986. 
Crisp R., "Compassion and Beyond", Ethical Theory and Moral Practice 11 [3] (2007 [2008]), pp. 233-246, https://doi.org/10.1007/s10677-008-9114-x.

Dictionary.com, https://www.dictionary.com/browse/wonder (accessed: 26.02.2019).

Ferrara A., The Force of the Example. Explorations in the Paradigm of Judgment, New York-Chichester 2008.

Kant I., The Critique of Judgment, transl. J.H. Bernard, London 1914.

Kant I., The Critique of Judgment, transl. W.S. Pluhar, Indianapolis-Cambridge 1987.

Kant I., Kritik der Urteilskraft, Leipzig 1922. Available at: https://archive.org/details/ kritikderurteils00kantuoft/page/n5 (accessed: 24.02.2019).

Nussbaum M.C., "Aristotle on Human Nature and the Foundations of Ethics", [in:] World, Mind, and Ethics: Essays on the Ethical Philosophy of Bernard Williams, J.E.J. Altham, R. Harrison (eds.), Cambridge 1995, pp. 83-131.

Nussbaum M.C., Frontiers of Justice Disability, Nationality, Species Membership, Cambridge-London 2007 (2006).

Nussbaum M.C., "Human Capabilities and Animal Lives: Conflict, Wonder, Law: A Symposium", Journal of Human Development and Capabilities 18 [3] (2017), pp. 317-321, https://doi.org/10.1080/19452829.2017.1342382.

Nussbaum M.C., Not for Profit. Why Democracy Needs Humanities, Princeton-Oxford 2010.

Nussbaum M.C., Political Emotions, Why Love Matters for Justice, Cambridge-London 2013.

Nussbaum M.C., The Therapy of Desire. Theory and Practice in Hellenistic Ethics, Princeton-Oxford 2009 (1994).

Nussbaum M.C., Upheavals of Thought. The Intelligence of Emotions, New York 2008 (2001).

Nussbaum M.C., Women and Human Development. The Capabilities Approach, New York 2000.

Oxford Advanced Learner's Dictionary, 8th Edition, Oxford 2010.

Vasterling V., "Cognitive Theory and Phenomenology in Arendt's and Nussbaum's Work on Narrative", Human Studies 30 (2007), pp. 79-95, https://doi.org/ 10.1007/ s10746-007-9050-0.

Zerilli L.M.G., A Democratic Theory of Judgment, Chicago-London 2016.

Zerilli L.M.G., Feminism and the Abyss of Freedom, Chicago-London 2005. 